\title{
Pendampingan Pengenalan Bahasa Inggris Sejak Dini dengan Belajar sambil Bermain melalui Bimbingan "English For Child" bagi Guru- Guru Raudhatul Athfal dan Paud
}

\author{
Merry Prima Dewi ${ }^{1}$, Ummil Fatzah ${ }^{2}$ and Zatiti ${ }^{3}$ \\ $1^{\text {st }}, 2^{\text {nd }}, 3^{\text {rd }}$ Institut Agama Islam Negeri Bukittinggi, Indonesia \\ E-mail: merryprimadewi@gmail.com, ummilfatzah@gmail.com, zatiti@gmail.com
}

\begin{abstract}
2021 by the authors. Submitted for possible open access publication under the terms and conditions of the Creative Commons Attribution-ShareAlike 4.0 International License-(CC-BY-SA) (https://creativecommons.org/licenses/by-sa/4.0/) do) DOI: $h$ ttp://dx.doi.org/10.30983/dedikasia.vlil.4980
\end{abstract}

\begin{tabular}{ll}
\hline \multicolumn{2}{l}{ ARTICLE INFO } \\
\hline Submit & $: 23$ Januari 2021 \\
Revised & $: 12$ Mei 2021 \\
Accepted & $:$ 30 Juni 2021
\end{tabular}

Keywords: English for child, Raudhatul athfal, PAUD
International License-(CC-BY-SA)

(https://creativecommons.org/licenses/by-sa/4.0/)

di) $h t$ tp://dx.doi.org/10.30983/dedikasia.vlil.4980

\begin{abstract}
The community service entitled Introduction to English from an early age by learning while playing through the guidance of "English for Child" is motivated by various problems indicating that children's language skills have not developed optimally, children are more silent, communicate less with their friends, many children cannot socialize and interact with others. environment. Children prefer to play alone rather than playing together with their friends, even in doing group assignments, children cannot do it together orwork together with their friends. the importance of language in human life, and the importance of English to be understood as the language of instruction in the international world, it is necessary to fostermotivation children'sto learn English from an early age withlearning fun. The importance of language in human life, and the importance of English to be understood as the language of instruction in the international world, it isnecessary to foster children's motivation to learn English from an early age withfun learning. The methodology in this study is in the form of research-based service with a participatory reporting approach. While the results of the service carried out can have an impact on Raudhatulteachers Athfal and PAUDso that they can applyway of teaching English

This is an open access article under the CC-BY-SA license
\end{abstract}

\section{Pendahuluan}

Bermain memiliki peran penting dalam perkembangan anak antara lain bidang perkembangan fisik motorik, bahasa, intelektual, moral, sosial, dan emosional. Kegiatan bermain dapat memberikan manfaat terhadap perkembangan fisik, motorik, bahasa, intelektual, moral, sosial, dan emosional anak. Untuk itu guru hendaknya memberikan kegiatan pembelajaran melalui bermain karena dunia anak adalah dunia bermain. Bermain merupakan kebutuhan bagi anak.

Belajar melalui bermain merupakan salah satu prinsip belajar di TK/RA (Taman KanakKanak/Raudhatul Athfal). Diharapkan dengan bermain anak akan dapat mengembangkan seluruh potensi yang dimilikinya, karena bermain merupakan kebutuhan bagi anak. Bermain juga dapat memberikan kesenangan dan kepuasan melalui aktivitas yang mereka lakukan. Sebagai tenaga yang 
profesional, seorang guru dituntut untuk dapat berinisiatif dan kreatif dalam menemukan serta menciptakan permainan - permainan yang menarik dan menyenangkan bagi anak. Permainan itu hendaknya dapat memicu perkembangan keterampilan, bahasa, sosial emosional, moral, fisik, motorik, konsep diri, serta interaksi dengan lingkungan.

Salah satu potensi yang harus dikembangkan di Raudhatul Athfal adalah kemampuan anak dalam berbahasa, namun kemampuan yang lainnya juga tidak kalah pentingnya. Anak seusia di tingkat TK/RA pada dasarnya memiliki kemampuan untuk meniru dan mencontoh kan apa yang ada di sekeliling mereka termasuk dalam berbahasa. Kemampuan berbahasa anak sudah bisa dilatihkan ketika anak pada masa usia di TK/RA.

Bahasa sangat menyatu dengan kehidupan manusia. Fungsi bahasa adalah sebagai alat komunikasi sosial. Setiap manusia adalah anggota masyarakat. Aktivitas manusia sebagai anggota masyarakat sangat tergantung pada penggunaan bahasa masyarakat. Harapan, keinginan, ide maupun harapan dan keinginan disampaikan melalui bahasa. Setiap masyarakat memiliki bahasa dan menggunakan alat komunikasi sosial tersebut. Bahasa merupakan hal yang penting dalam kehidupan manusia. Bahasa menyatu dalam kehidupan manusia. Sejak manusia lahir maka bahasa telah menjadi menyatu dalam kehidupan manusia. Bahasa juga menandakan keberadaan manusia. Bahasa merupakan akar kebudayaan manusia. Kebudayaan manusia hidup dan berkembang diwariskan karena adanya bahasa yang mendukungnya.

Bahasa Inggris merupakan salah satu bahasa dunia internasional, disamping bahasa Arab dan bahasa Mandarin. Bahasa-bahasa dunia internasional tersebut sebaiknya diperkenalkan pada anak sejak dini agar tumbuh minat dan motivasi anak untuk mempelajarinya. Bisa dibayangkan, ketika berada di negara luar sementara kemampuan berbahasa Inggris tidak dimiliki, maka akan kesulitan dalam membaur atau bersosialisasi di negara asing tersebut. Komunikasipun bisa terputus akibat ketidakmampuan berbahasa.

Pengamatan yang ditemukan di lapangan pada beberapa Raudhatul Athfal dan PAUD Islam di kabupaten Pasaman terindikasi kemampuan berbahasa anak belum berkembang secara optimal, anak lebih banyak diam, kurang berkomunikasi dengan teman2nya, banyak anak tidak bisa bersosialisasi dan berinteraksi dengan lingkungannya. Anak lebih suka bermain sendiri ketimbang bermain bersama dengan temannya, bahkan dalam mengerjakan tugas kelompok anak belum bisa mengerjakannya secara bersama-sama atau bergotong royong dengan temannya. Anak kelihatan lebih mementingkan diri sendiri dan tidak peduli dengan orang lain. Selain itu guru kurang menciptakan permainan permainan yang menarik dalam rangka membantu mengembangkan bahasa anak khususnya pengenalan bahasa Inggris. Padahal bahasa Inggris merupakan bahasa internasional yang perlu untuk dikenal anak sejak dini. Penelitian yang dilakukan oleh Nurmi (2011) mengenai rendahnya keterampilan sosial anak TK di kecamatan Bonjol Pasaman, maka Nurmi melakukan penelitian tindakan kelas (PTK) dengan permainan tradisional dengan kesimpulan bahwa permainan dapat untuk menumbuhkembangkan keterampilan sosial anak. 


\section{Metodologi}

Metode yang dipakai dalam program pengabdian masyarakat berbasis penelitian ini di Raudhatul Athfal dan PAUD Islam di Nagari Limo Koto melalui metode Service Learning dengan memberikan layana berupa pendampingan dan pelatihan bagi guru Raudhatul Athfal dan PAUD untuk pengembangan keterampilan sosial anak sejak dini melalui permainan yang menyenangkan. Pendekatan-pendekatan yang lebih praktis sifatnya sangat dibutuhkan dalam proses pengabdian berbasis penelitian di Raudhatul Athfal dan PAUD nagari Limo Koto Kumpulan.

Beberapa pendekatan yang akan dipakai antara lain:l. Partisipasi, pendekatan partisipasi menempatkan keterlibatan berbagai pihak dalam kegiatan pengabdian yang berbasis penelitian ini. 2 . Pathership, membangun kemitraan (pathership building) merupakan salah satu pendekatan yang sangat efektif diterapkan ke dalam program-program yang sifat dan lingkupnya melingkupi aspek yang cukup luas. Sasaran dari partnership adalah membangun keterbukaan, akuntabilitas, juga membangun kontrol bersama, yang diharapkan mampu menumbuhkan trust bersama dari pihak-pihak yang terkait dalam program ini antara lain: lembaga pendidikan, pemerintah daerah/nagari/desa dan tokoh masyarakat.3. Networking (jaringan kerja) sangat bermanfaat untuk membangun semangat visi gerakan bersama. Kerjasama antara masyarakat dapat berfungsi sebagai kekuatan-kekuatan dalam kegiatan pengabdian yang berbasis penelitian ini. 4. Process Oriented (Menghargai Proses), pendekatan yang mencurahkan perhatian pada process oriented ditujukan untuk mempersiapkan secara sungguh-sungguh pengabdian berbasis penelitian di Raudhatul Athfal dan PAUD di nagari Limo Koto.

\section{Hasil}

Pelaksanaan pengabdian masyarakat dalam menumbuhkembangkan kemampuan keterampilan berbahasa pada anak usia dini di lembaga pendidikan Raudhatul Athfal dan PAUD Islam melalui kegiatan pengabdian masyarakat dengan judul pengenalan bahasa Inggris sejak dini melalui belajar sambil bermain melalui bimbingan English for child bagi guru-guru Raudhatul Athfal dan PAUD Islam yang ada di kenagarian Limo Koto. Kebijakan pemerintah kabupaten Pasaman dengan mencanangkan program "satu jorong satu paud" menjadikan lembaga pendidikan RA/PAUD tumbuh berkembang di kenagarian Limo Koto sebagai bentuk menjawab dan merespon program pemerintah kabupaten Pasaman tersebut. Dalam upaya melaksanakan kegiatan pengabdian masyarakat bagi lembaga pendidikan Raudhatul Athfal (RA) dan PAUD Islam, setelah mendapat kepercayaan dari Institut Agama Islam Negeri (IAIN) Bukittinggi melalui Lembaga Penelitian dan Pengabdian Masyarakat (LP2M) dengan memanfaat dana BOPTN tahun 2018, maka dilakukanlah beberapa rangkaian kegiatan pengabdian sesuai dengan acuan Direktorat Pendidikan Tinggi Islam (Diktis) Kemenag RI. 
Kegiatan Sosialisasi Pembelajaran Sambil Bermain dan Menyenangkan Bagi Anak RA/PAUD Islam. Sosialisasi pembelajaran menyenangkan sambil bermain bagi anak usia dini dilaksanakan dalam bentuk workshop. Kegiatan Sosialisasi berupa workshop pengabdian masyarakat mensosialisasikan bagaimana dunia anak. Dunia anak dalam pengabdian pada awalnya anak belum diperkenalkan dengan bahasa asing yang mudah dan sederhana, yang menyenangkan bagi anak. Pengabdi mendiskusikannya dengan guru, lalu disepakati untuk memberikan pendampingan dan pelatihan. Perkembangan anak dan dunia bermain bagi anak bagi guru-guru Raudhatul Athfal dan PAUD Islam melalui Sosialisasi dan workshop pembelajaran sambil bermain dan menyenangkan bagi anak-anak Raudhatul Athfal dan PAUD Islam bagi guru-guru Raudhatul Athfal (RA) dan Pendidikan Anak Usia Dini (PAUD) Islam di kenagarian Limo Koto dilaksanakan dilaksanakan pada 08-09-2018 yang bertempat di PAUD Islam Cahaya Hati Jalan Raya Bukittinggi-Lubuk Sikaping Jorong Batu Badinding Utara Nagari Limo Koto.

Kegiatan sosialisasi, pendampingan dan pelatihan dilakukan dengan menghadirkan narasumber yang kompeten di bidang pembelajaran bahasa Inggris dan bidang ilmu pendidikan. Sosialisasi dan workshop pengenalan bahasa Inggris sejak dini melalui pembelajaran sambil bermain dan menyenangkan melalui bimbingan English for Child bagi guru-guru RA/PAUD ini dipandang perlu karena mengingat guru-guru di RA/PAUD Islam di kenagarian Limo Koto pada dasarnya sudah memiliki dasar-dasar kompetensi seorang guru seperti kompetensi pedagogik, kompetensi sosial, kompetensi personal, dan kompetensi profesional namun keterbatasan berbagai hal seperti sarana dan prasarana, biaya dan sebagainya sehingga guru RA/PAUD Islam di kenagarian Limo Koto jarang sekali mendapatkan pembekalan ataupun pelatihan. Sungguhpun serba keterbatasan dan kekurangan sarana dan prasarana namun semangat para guru-guru RA/PAUD Islam dalam memperoleh pengetahuan tetap kuat dengan harapan dapat memberikan pembelajaran yang terbaik untuk peserta didik mereka.

Kegiatan sosialisasi berupa pelatihan dan pendampingan pengenalan bahasa Inggris sejak dini melalui pembelajaran sambil bermain dan menyenangkan bagi guru-guru RA/PAUD Islam penting untuk dilakukan sebagai upaya mengembangkan potensi dan kemampuan guru-guru RA/PAUD Islam dalam mengajar khususnya mengajarkan bahasa Inggris sejak dini melalui pembelajaran sambil bermain dan menyenangkan bagi anak. Hal ini dipandang urgen mengingat usia anak adalah usia untuk mengembang kemampuan dan potensi termasuk kemampuan berbahasa. Peran seorang guru pada dasarnya tidak hanya mengajar tetapi lebih dari itu berupa mengembangkan potensi anak termasuk potensi berbahasa dan berkomunikasi anak.. Dengan demikian kegiatan sosialisasi pengenalan bahasa Inggris sejak dini bagi anak RA/PAUD Islam melalui pembelajaran menyenangkan sambil bermain sangat perlu dan penting diberikan melalui sosialisasi dan workshop agar pembelajaran di RA/PAUD begitu menyenangkan bagi anak-anak yang dunianya dikenal dengan dunia bermain.

1. Pendampingan dan pelatihan Pengenalan Bahasa Inggris Sejak Dini Dengan Belajar Sambil Bermain Melalui Bimbingan English For Child Bagi Guru-Guru Raudhatul Athfal dan PAUD.

Kegiatan pendampingan dan pelatihan pengenalan pembelajaran Bahasa Inggris sejak dini dengan belajar sambil bermain melalui bimbingan english for child bagi guru-guru Raudhatul 
Athfal (RA dan PAUD Islam) berupa lokakarya dan pelatihan mengenai bagaimana memperkenalkan pembelajaran bahasa Inggris sejak dini dengan belajar sambil bermain melalui bimbingan English for child dengan pembelajaran yang menyenangkan sehingga anak usia dini tidak merasa terbebani dengan pembelajaran justru sebaliknya si anak akan menjadi senang karena sambil bermain pada dasar mereka sedang belajar.

Pendampingan dan Pelatihan berupa lokakarya dan pelatihan pengenalan bahasa Inggris sejak dini dengan belajar sambil bermain melalui bimbingan English for child bagi guru-guru Raudhatul Athfal dan PAUD Islam se Kenagarian Limo Koto dilaksanakan pada tanggal 21-92018. Kegiatan ini dilaksanakan dengan mendatangkan narasumber yang kompeten dibidangnya dengan harapan dapat memberikan pemahaman yang mendalam kepada peserta pelatihan.

Kegiatan pendampingan dan pengenalan bahasa Inggris sejak dini dengan belajar sambil bermain melalui bimbingan english for child bagi guru-guru Raudhatul Athfal dan PAUD Islam se Kenagarian Limo Koto dilaksanakan agar guru-guru RA/PAUD Islam dapat menerapkannya sehingga bahasa Inggris sudah dikenal oleh anak sejak dini sebagai suatu pelajaran yang menyenangkan bukan pelajaran yang susah dan menakutkan. Dengan latihan-latihan yang diberikan kepada guru, pemahaman guru akan sebuah lebih kuat dan mendalam bahwa bahasa Inggris perlu dikenal oleh anak sejak dini sebagai bahasa Internasional dan pembelajaran yang menyenangkan.

Pendampingan dan pelatihan berupa lokakarya. urgent untuk dilaksanakan karena secara keilmuan bahwa untuk mencapai sebuah tujuan dalam pembelajaran maka pembelajaran atau kegiatan yang dilakukan hendaklah dengan mempraktekkannya secara langsung. Lokakarya dan Latihan ini berupa praktek ini diharapkan dapat dicapai oleh peserta workshop hal ini didasarkan pada sistem pembelajaran bahwa tujuan merupakan komponen yang utama untuk mencapai tujuan.

2. Workshop Penguatan Pengenalan Pembelajaran Bahasa Inggris Sejak Dini Dengan Belajar Sambil Bermain Melalui Bimbingan English For Child bagi Guru Raudhatul Athfal dan PAUD Islam. Workshop dan FGD Penguatan pengenalan bahasa Inggris sejak dini dengan belajar sambil bermain melalui bimbingan English for Child bagi guru-guru Raudhatul Athfal dan PAUD Islam dilaksanakan di PAUD Islam Cahaya hati yang terletak di Panampung Jorong Batu Badinding Utara nagari Limo Koto pada tanggal 22-9-2018. FGD dan Workshop penguatan pengenalan bahasa Inggris sejak dini dengan belajar sambil bermain melalui bimbingan English for Child bagi guru-guru Raudhatul Athfal dan PAUD Islam di kenagarian Limo Koto bertujuan agar kegiatan pendahulu nya berupa sosialisasi dan lokalatih lebih kuat pemahamannya oleh 
guru RA/PAUD Islam dengan dilaksanakan kegiatan penguatan berupa workshop dan Focus Group Discussion (FGD).

Pemikiran dan pertimbangan yang mendasari untuk dilaksanakannya penguatan pengenalan bahasa Inggris sejak dini dengan belajar sambil bermain melalui bimbingan English for Child bagi guru-guru RA/PAUD Islam ialah bahwa guru memiliki tanggung jawab untuk membimbing dan mengarahkan anak-anak didiknya apalagi untuk mengembangkan fisik dan psikisnya anak didiknya. Dengan memperkenalkan bahasa Inggris dengan bermain pada anak dengan sendirinya guru telah menanamkan nilai-nilai dan mental yang kuat untuk anak untuk mengenal bahasa Asing sejak dini. Tidak kalah pentingnya dengan pengenalan dengan pembelajaran sambil bermain sebagai hal yang menyenangkan bagi anak, membangun pemikiran anak bahwa bahasa Inggris merupakan hal menyenangkan bukan hal yang sulit atau membosankan.

3. FGD Pendalaman Materi Pengenalan Bahasa Inggris Sejak Dini Dengan Belajar Sambil Bermain Melalui Bimbingan English For Child Bagi Guru-Guru Raudhatul Athfal dan PAUD.

Focus Group Discussion dan workshop Pendalaman materi pengenalan bahasa Inggris sejak dini dengan belajar sambil bermain melalui bimbingan English for Child bagi guru-guru Raudhatul Athfal dan PAUD Islam sebagai bentuk kegiatan pendalaman materi agar kegiatan pengabdian yang dilaksanakan sebelumnya dapat dipahami atau ada feedback berupa masukan dari peserta bagaimana sebaiknya kegiatan dilakukan.

Kegiatan Focus Group Discussion pendalaman materi pengenalan bahasa Inggris sejak dini melalui bimbingan belajar sambil bermain bagi guru-guru Raudhatul Athfal dan PAUD Islam dilaksanakan pada tanggal 29-09-2018 bertempat di PAUD Islam Cahaya Hati yang beralamat jalan Raya Bukittinggi-Lubuk Sikaping tepatnya Panampung Jorong Batu Badinding Utara Kenagarian Limo Koto. Dalam kegiatan ini didiskusikan mengenai cara-cara efektif dalam memperkenalkan bahasa Inggris sejak dini dengan belajar sambil bermain melalui bimbingan English for Child bagi guru-guru Raudhatul Athfal dan PAUD Islam dari narasumber dan dengan masukan-masukan dari peserta yang akan menerapkan pengenalan bahasa Inggris sejak dini kepada anak-anak RA/PAUD Islam. Kombinasi antara narasumber yang kaya materi dengan guru-guru RA/PAUD yang kaya akan pengalaman akan menjadi kombinasi yang luar biasa dalam kegiatan diskusi tersebut. Diskusi dalam bentuk Focus Group Discussion diharapkan akan terjadi pendalaman materi bagi peserta untuk dapat memahami dan menerapkannya dalam pembelajaran.

Pembelajaran yang mengasyikkan dan menyenangkan menjadi dambaan peserta didik dalam menjalani proses pembelajaran. Aktivitas pembelajaran yang menyenangkan menjadi suatu yang akan terkenang dan dikenang oleh peserta didik ketika peserta didik tidak lagi sebagai 
murid atau siswa. Bahkan seorang anak akan memilih pendidikan lanjutan atau memilih pekerjaannya ketika dewasa dengan pertimbangan pengalaman ketika menjadi siswa dibangku sekolah. Tidak sedikit orang menjadi dokter karena pelajaran biologi yang menyenangkan ketika di bangku sekolah. Tidak sedikit juga orang menjadi ahli fisika atau ahli kimia, ketika mendapatkan pelajaran tersebut dengan rasa senang dan mengasyikkan. Demikian juga halnya dalam pembelajaran bahasa Inggris, tidak sedikit pula orang menjadi diplomat, ahli bahasa dikarenakan kesenangan ketika belajar bahasa Inggris ketika dibangku sekolah.

Sehubungan dengan pembelajaran bahasa Inggris sejak dini bagi peserta didik tingkat RA dan PAUD, juga dapat memberikan pengaruh besar dalam mencintai suatu bahasa, jika sekiranya pembelajaran bahasa Inggris itu disajikan dalam pembelajaran yang menyenangkan sehingga peserta didik merasa senang dan tidak merasa terpaksa atau tertekan. adapun batasan yang diberikan tentang pengertian bermain, bermain membawa harapan dan antisipasi tentang dunia yang memberikan kegembiraan dan memungkinkan anak berkhayal seperti sesuatu atau seseorang, suatu dunia yang dipersiapkan untuk berpetualang. Melalui bermain anak belajar mengendalikan diri sendiri, memahami kehidupan, memahami dunianya. Jadi bermain merupakan cermin perkembangan anak.

Bermain bagi dunia anak menjadi suatu yang tidak dapat diabaikan, karena bermain sangat penting bagi pertumbuhan dan perkembangan anak. Para ahli sepakat, anak-anak harus bermain agar mereka dapat mencapai perkembangan yang optimal. Tanpa bermain anak akan bermasalah dikemudian hari, bahwa anak bermain karena mereka punya energi berlebih. Energi ini mendorong mereka untuk melakukan aktivitas sehingga mereka terbebas dari perasaan tertekan. Anak bermain karena mereka memerlukan penyegaran kembali atau mengembalikan energy yang habis digunakan untuk kegiatan rutin sehari-hari. Anak dapat mengembangkan rasa harga diri melalui bermain, karena dengan bermain anak memperoleh kemampuan untuk menguasai tubuh mereka, benda-benda dan keterampilan sosial.

\section{Pembahasan}

Kegaiatan pengabdian masyarakat berbasis service learning masyarakat yang dilakukan pengabdi IAIN Bukittinggi mengenai "Pengenalan bahasa Inggris sejak dini dengan belajar sambil bermain melalui bimbingan English for child bagi Raudhatul Athfal dan PAUD di RA/PAUD se kenagarian Limo Koto yang didanai oleh dana BOPTN dengan melalui proses yang cukup panjang muai seleksi proposal pengabdian masyarakat berbasis riset sampai kepada penetapan pengabdi yang di SK kan oleh Rektor berdasarkan surat keputusan Rektor maka dapat ditarik satu simpulan bahwa pengenalan bahasa Inggris untuk anak usia dini dengan belajar sambil bermain melalui bimbingan english for child dapat menjadikan pembelajaran sebagai sesuatu yang menyenangkan bagi anak. Bahasa 
Inggris yang disajikan dengan bermain membuat anak menjadi senang dalam mengikuti pembelajarannya. Kegembiraan anak dengan pembelajaran sambil bermain menjadikan anak menyukai pembelajaran bukan sebaliknya menjadi bosan dan momok menakutkan terhadap suatu mata pelajaran.

Permainan cukup penting bagi perkembangan jiwa anak-anak oleh karena itu perlu kiranya bagi anak-anak untuk diberi kesempatan dan sarana di dalam kegiatan permainannya. Permainan yang diberikan tersebut hendaknya berupa permainan-permainan edukatif. Dimana permainan tersebut diposisikan sebagai sarana untuk pendampingan anak yang aktif, efektif, dan menyenangkan serta lebih mendayagunakan.

Teori yang dihasilkan dari pengabdian masyarakat yang berjudul pengenalan bahasa Inggris sejak dini dengan belajar sambil bermain melalui bimbingan english for children bagi guru-guru Raudhatul Athfal dan PAUD Islam adalah anak menemukan dan menciptakan suasana kesenangan dan kegembiraan serta mengembangkan sikap ingin tahu yang lebih mendalam dengan gembira. Secara teori dapat diangkat temanya berupa :Belajar sambil bermain dan bermain melalui belajar"

Beberapa temuan diatas sesuai dengan pendapat ahli pendidikan anak usia dini M. Subhi dengan menguraikan tujuan-tujuan dari permainan edukatif. Dimana permainan-permainan dalam belajar bahasa Inggris dengan konsep belajar sambil bermain melalui english for child. Menurut M. Subhi (2009:151) tujuan dari permainan-permainan edukatif tersebut adalah :

1. Melatih kemampuan berpikir logis anak.

2. Menumbuhkembangkan kemampuan dalam mengatasi masalah (problem solving)

3. Menambah informasi dan kemampuan anak

4. Melatih anak dalam mengambil keputusan yang benar

5. Melatih anak mempunyai sejumlah strategi dan alternative yang sesuai

Bermain di sekolah dapat membantu perkembangan anak apabila guru cukup memberikan waktu, ruang, materi dan kegiatan bermain bagi murid-muridnya. Anak-anak membutuhkan waktu tertentu agar dapat mengembangkan keterampilan dalam memainkan sesuatu alat permainan. Anak yang lebih matang akan mampu melakukan kegiatan bermain dalam waktu yang lebih panjang dibandingkan anak yang masih uda usia yang hanya mampu bermain dalam jangka waktu yang lebih pendek. Tersedianya ruang dan materi mainan merupakan prasarat terjadinya kegiatan bermain yang produktif.

Bermain adalah dunia sekaligus sarana belajar anak. Memberikan kesempatan kepada anak untuk bermain berarti memberikan kesempatan kepada anak untuk belajar dengan cara-cara yang 
dapat dikategorikan sebagai bermain. Bermain membuat pengalaman belajar itu dirasakan dan dipersepsikan sehingga menjadi bermakna baginya. Menurut Slamet (2005:124-126) bermain memiliki peran penting dalam perkembangan anak antara lain bidang perkembangan fisik motorik, bahasa, intelektual, moral, sosial, dan emosional, secara sepintas dijelaskan sebagai berikut :

1. Bermain mengembangkan kemampuan motorik. Berbagai penelitian menunjukkan bahwa bermain memungkinkan anak bergerak secara bebas sehingga anak mampu mengembangkan kemampuan motoriknya

2. Bermain mengembangkan kemampuan kognitif. Horn dalam Slamet (2005:125) menunjukkan bahwa bermain memiliki peran yang sangat penting dalam mengembangkan kemampuan berpikir logis, imajinasi dan kreativitas.

3. Bermain mengembangkan kemampuan afektif. Setiap permainan memiliki aturan. Aturan akan diperkenalkan oleh teman bermain sedikit, tahap demi tahap sampai setiap anak memahami aturan mainnya. Oleh karena itu, bermain akan melatih anak dalam menyadari akan adanya aturan dan pentingnya mematuhi aturan.

4. Bermain mengembangkan kemampuan bahasa. Pada saat bermain anak didik menggunakan bahasa, baik untuk berkomunikasi dengan temannya atau sekedar menyatakan pikirannya. Hal ini secara tidak langsung anak belajar bahasa

5. Bermain mengembangkan kemampuan sosial. Pada saat bermain anak berinteraksi dengan anak yang lain. Interaksi tersebut mengajarkan anak bagaimana merespon memberi dan menerima, menolak atau setuju ide dan perilaku anak lain.

\section{Penutup}

Pengenalan bahasa Inggris sejak dini dengan belajar melalui bermain dan bermain sambil belajar melalui bimbingan english for child bagi guru-guru Raudhatul Athfal dan PAUD menjadi suatu tuntutan agar anak sejak dini diperkenalkan dengan bahasa internasional sebagai bahasa pengantar dalam forum ilmiah atau bahasa pengantar dalam berkomunikasi di dunia internasional. Mengingat anak usia dini adalah anak dengan dunia bermain maka pembelajaran bahasa Inggris untuk anak usia dini disesuaikan dengan tingkat perkembangan mereka yaitu dunia bermain. Tuntutan akan bahasa pengantar internasional seperti bahasa Inggris perlu diperkenalkan sejak dini mengingat anak akan hidup di era globalisasi yang sarat dengan interaksi dan komunikasi masyarakat global. Persoalan dan tantangan kehidupan yang sarat dengan interaksi dan komunikasi masyarakat global maka diperlukan anak-anak yang siap dengan pola interaksi dan komunikasi tersebut dengan kemampuan menggunakan bahasa internasional salah satunya adalah bahasa Inggris. Untuk menjawab tantangan di atas, kegiatan pengabdian masyarakat berbasis riset untuk meningkat memperkenalkan bahasa Inggris sejak dini dengan konsep belajar melalui bermain dan bermain sambil belajar melalui bimbingan english for child bagi guru Raudhatul Athfal dan PAUD di kenagarian Limo Koto merupakan 
bentuk nyata dari pengabdian masyarakat yang dilakukan agar guru RA/PAUD Islam di kenagarian Limo Koto mampu mengajarkan bahasa Inggris sejak dini pada anak melalui belajar sambil bermain. Pengabdian masyarakat berbasis riset yang dilakukan guru-guru PA/PAUD di kenagarian Limo Koto telah memberikan dampak yang signifikan terhadap guru-guru RA/PAUD, hal ini terlihat dari antusiasme peserta untuk mengikutinya dari awal kegiatan pengabdian sampai pada akhir kegiatan yang dilaksanakan secara marathon dari minggu ke minggu sesuai dengan kontrak kerja pengabdian masyarakat. 


\section{Daftar Pustaka}

Depdiknas. 2005. Kurikulum 2004 Standar Kompetensi. Jakarta : Direktorat jenderal Manajemen Pendidikan Dasar dan Menengah 2007. Pedoman Pembelajaran Bidang Pengembangan Pembiasaan di Taman Kanak - Kanak. Jakarta : Direktorat Pembinaan Taman Kanak - Kanak dan Sekolah Dasar.

2009. Pembinaan Kepribadian Anak TK Berbasis Pendidikan Multi Kultural. Jakarta : Direktorat Pembinaan Taman Kanak - Kanak dan Sekolah Dasar.

Hurlock.E.B. 1991. Perkembangan Anak. Jilid I. Edisi ke 6. Jakarta : Erlangga

Moeslichatoen R. 2004. Metode Pengajaran di Taman Kanak - Kanak . Jakarta : Rineka Cipta.

Montolalu.BEF.dkk. 2005. Bermain dan Permainan Anak. Jakarta : Universitas Terbuka.

Slamet Suyanto. 2005. Konsep Dasar Pendidikan Anak Usia Dini. Jakarta : Depdiknas

M. Subhi Abussalam. 2009. Langkah Mudah Gali Potensi Sebuah Hati. Solo : Pustaka Iltizam 